\title{
Interactive Digital Games for Geography Teaching and Understanding Geographical Space
}

\author{
Christian Nunes da Silva \\ Federal University of Pará, (UFPA), Belém, Brazil \\ Email: cnunes@ufpa.br \\ Received 19 February 2015; accepted 12 May 2015; published 15 May 2015 \\ Copyright (C) 2015 by author and Scientific Research Publishing Inc. \\ This work is licensed under the Creative Commons Attribution International License (CC BY). \\ http://creativecommons.org/licenses/by/4.0/

(c) (i) Open Access

\begin{abstract}
This article aims to analyze and discuss the use of digital interactive games, such as learning tools to be used by educators in the classroom, as a resource for geography teaching-learning process in the early grades. This discussion arose from the analysis by geography course graduation students of the Federal University of Pará (UFPA), in the years 2013 and 2014, at which this tool has gained recognition of its potential by students. In this sense, the objective is a brief discussion, based on the analysis of some selected examples on how these digital games can become fundamental importance of resources for teaching Geography and how these should be used and applied in the classroom by educators in a critical way, which will allow students to have adequate learning about the geographic space.
\end{abstract}

\section{Keywords}

Digital Interactive Games, Geography Teaching, Teaching-Learning Process

\section{Introduction}

In recent decades, the Geography teaching ${ }^{1}$ has undergone a series of transformations, especially in relation to development of technical and cartographic representation, with emphasis on the progress achieved with the use of computers and advances in the collection and dissemination of spatial information (Taylor, 2010). However,

\footnotetext{
${ }^{1}$ We understand the Geography Teaching as a set of practices, methodologies and techniques directed to construction of geographical knowledge in school. Therefore, we consider as target children, youth and adults that aims the understanding of natural environments and the activities of society in the space changes. However, the construction of knowledge about the geographic space is guided in recognition of geographical concepts and categories (space, territory, region, location, etc.), which help the teacher in the teaching-learning process.
} 
to remember the relations processed in society is also necessary to observe the activity of concerned educators in teaching about the occupation of geographic space related to interference of individuals in the landscape configuration. Thus, the role of the educator should be to guide the criticality of the students, so that this assists directly in the formation of professional/citizen who is being formed, whose perception is reflected in the human and natural works.

From the 1980s, the traditional way of teaching geography began to be questioned by some educators. What had been disputed concerned the manner of how this teaching was being held, that is, teachers limited to the description of natural landscapes and its formative elements without, however, provide necessary support to students so that they understand the transformations that are happening in the world and so they could develop their own reflections. It is the role of geography and cartography, for example, to make the world more understandable for students. Nowadays, it makes sense to present a static and mechanical description of facts and events. It is necessary to show that the globalized world is dynamic and liable to change.

From this perspective, some educators changed their ways to teach and evaluate, making it possible to take into consideration the student's behavior in the classroom, in their daily life and also in their relationship with society. For this, the process of teaching and learning should not be restricted to simple expository and inflexible classes with random enforcement activities and notes, or the application of tests at the end of a school year, with the aim of assessing student learning.

Currently, this process should be considered continuous and systematic, which has "energizing” function, in order to stimulate the student to have dedication to the work proposed by the teacher. Thus, the teacher must also use questionnaires, observation, participation and various mechanisms to cooperate significantly with the teaching activity without content fail to consider other resources, i.e. lectures in class and applying final tests. According to Selbach (2010) it is important to note that in all the teaching-learning process the teacher should use tools that help them in their teaching practice, which can be: projects, drama, music, research, group work and debates among students, etc. strategic tools and considered as stimulants forms of assessment, in order to promote learning.

Thus, through bibliographic searches on sites on the World Wide Web, initially we will briefly discuss the teaching of Geography as a discipline and then analyze some digital interactive games as educational tools available for use by educators from various school subjects (Geography, Biology, History, Sociology, Portuguese, etc.). In that case, it will discuss about the use of interactive games in computing environment that can be used during geography lessons, in order to streamline lessons and instigate discussion with students about the geographic space that surrounds them.

\section{The Geography Teaching}

To Silva (2003) the process of teaching and learning should be thought of as a practice that sees the students as subjects belonging to a certain point, where the teacher is the facilitator of the learning process, and is committed to teaching practice, aiming a direct relationship between the content transmitter and assimilating the same, i.e. the teacher-student relationship, being the educator the organizer and planner of their own practice through critical methods and which are really committed to student learning and the construction of knowledge. However, what can be seen, in the case of Geography teaching that we find in some Brazilian schools, is a teaching based on content fleeing the reality of the students (Sposito, 2006), uncompromised with the social context of them, reinforced by a traditional teaching method-decorative and encyclopedic, which inhibits critical of students the environment where they belong.

To Cavalcanti (2002: p. 13), this fact is contradictory to the actual role of geography as a science and discipline in the classroom, because:

Geography is the science that studies, analyzes and tries to explain (to know) the space produced by man and, as a matter of education, it allows the student to be perceived as a participant of the spatial studies, where the phenomena occurring there are results of life and work of men and are inserted in a development process.

In this sense, the geography content that is taught/transmitted to the students, does not include in its speech a critical view of reality to be studied, providing an uninteresting content that evades reality, significantly compromising the learning of them and stimulating a vision that geography is a decorative and dull discipline to be studied. This conception of the geographical science was built and permeates the Brazilian Geography teaching to the present day, because, for a long time, it was historically neglected its true social role (Lacoste, 1989), as a 
training tool of critical subjects and analytical their social space. This contributes to building a neutral and unengaged science.

During that time, it was theoretically and methodologically formulated as a science of space description, landscape and regional crop. However, this descriptive method, which the Geographic Science was titled, began to receive criticism from the 1950s, due to the emergence of new theoretical and methodological background and its positioning to the context of this decade, that is, before the structural changes to which the society had now. So, Geography needed to insert in this process of change and reformulations.

In this sense, from the 1970s Geography began to receive significant contributions from authors who walked to the encounter with a new theoretical and methodological proposal for Geographic science, the construction of a science that is concerned to form a thinking society and critical to their space, different from the Geography in the description, which promoted one geographic knowledge for strategic purposes, restricted to particular interests (Lacoste, 1989), a knowledge that was denied to citizens (Moreira, 2006), because in universities and schools it was censored not participating in the training of teachers and students because it "distorted them." Therefore, man as a social being inserted in this building process needed to be aware of this socio-spatial formation which was inserted from an analytical and critical direction. Therefore, the teaching of Geography needed to take a position on the current situation which the Geographic Science was being structured theoretical and methodological.

Thus, at present, there was a "rescue" of the geographical science education, as of reformulations occurred in the teaching of Geography, before the longing for a position that would strengthen the role of geography as a training science of conscious and critical subject, before the training/construction of their social space. These changes were perceived in the educational system with the direct and indirect performance of researchers, educators and students who contributed to the consolidation of this change. Therefore, new methods and practices were oriented to meet this craving (Silva, 2003).

However, it is no consensus that this critical method of teaching Geography has been successfully accepted in all Brazilian school environments or with all the methods and practices of building geographic knowledge. An important theoretical and methodological contribution to the geography teaching should be conducted for purposes of achieving the propositions previously expected-a critical geography for the purpose of providing a position on the critical and analytical role of the same, is proposed by Straforini, that "(...) the dialectical understanding of the educational process implies and presupposes that the process of knowledge construction is done according to the process by which individuals are going” (Straforini, 2004: p. 68).

In this sense, Straforini contribution demonstrates its position regarding the role of geography education in the construction of understanding the reality of students, the space lived by them, by means of the categories, concepts and themes dealt with by Geography, jointly, between student and educator, where geographical representations are built to a better geographical knowledge and not something passed on to them through positivist methods without the participation/interaction between them. To Straforini (2004: p. 51):

We can no longer deny the reality of the student. Geography should necessarily provide for the construction of concepts that enable the student to understand their present and thinking about the future responsibly, or even worry about the future through the nonconformity.

That is, despite the Geography teaching still suffer great influence of the traditional method, it is gradually being constructed from a new method (Francischett, 2011), concerned about the students as subjects and not as simple external content receptacle its historical and social reality. Thus, Geography, although known for some time as an important tool in the geographic space education, should contribute to students' learning process to be favored by a method that lead them to see it as a subject that belongs with the other contents taught, providing an assimilation to facilitate the seizure according to the cognitive levels, acting in a thinking manner in the society in which it operates and equipping it so it can understand their reality to interfere in it consciously. Digital interactive games can help to fulfill this role, teaching the geographic space, in order to understand the social and environmental reality.

\section{Interactive Digital Games for Geographical Space Education}

Nowadays, a major challenge for teachers is to overcome the traditional teaching method, which has proven ineffective in the teaching-learning process which, every day, goes off in an efficient connection between the speaker (educator) and the receiver (student) in the construction of geographical knowledge. In short, finding 
new ways of teaching is one of the great challenges of schools today. The use of resources on which to effectively support and also allow students the expected understanding of the content also makes each day more necessary, it means, process in which the playful aspect and knowledge walk together because learning should not only be an obligation, but a pleasurable activity.

The games have always been effective mechanisms to teach, in a playful way, various issues in the classroom because the activities with recreational character attract the attention of students and become important tools for teaching and understanding of geographical space (Neves, Nascimento, \& Carvalho, 2013). The educator can resort to the use of different methodologies involving interactive games for the dynamization of his class. In this case, not necessarily the games should have direct connection with the use of computers, but should be related to the subject and the methodology chosen to facilitate the teaching-learning process.

The use of traditional games such as "treasure hunt" or "battleship" are methodological practices long applied by educators in the classroom to explain the location and address the objects and phenomena that take place on Earth surface and, with the advent of computers, the ludic way of working with interactive games in geography teaching could be strengthened. With the use of computational environment in games, the educator has made it possible to motivate more and more the student body to handle these games and thus better understand the geographic strategies that can be related to the subject discussed in class.

Figure 1 shows the main screen of geo-game ${ }^{2}$ "Battleship" before practiced out of the computer, on a board, but now in digital media, more apps can be added, sounds and icons that can be used in the discussion of geographic network coordinates with examples of what are the meridians and parallels and stimulating development of guidance for students (compass, left, right, north, south, east, west, northeast, southeast, etc.).

The creation of other tradicional "board games", such as Battleship, who migrated and were incorporated by computer, comes leveraging the explanations of the geographical space and their attributes, in classes of those educators who have access and knowledge on how to enter in their professional daily life knowledge about aggregated content with the benefits of computers and the internet.

As an example of interactive games that has the geographical strategy its main focus we have the games known as RPG (Role-Playing Game), which are games, with pre-defined rules, where users must manipulate their avatars (characters) to occupy territories (fictional or not) from other players, live with other users, or simply collect resources for a given "civilization" existing in the game. Importantly, there are many games of this type, which can be worked in print, or are available on the internet.

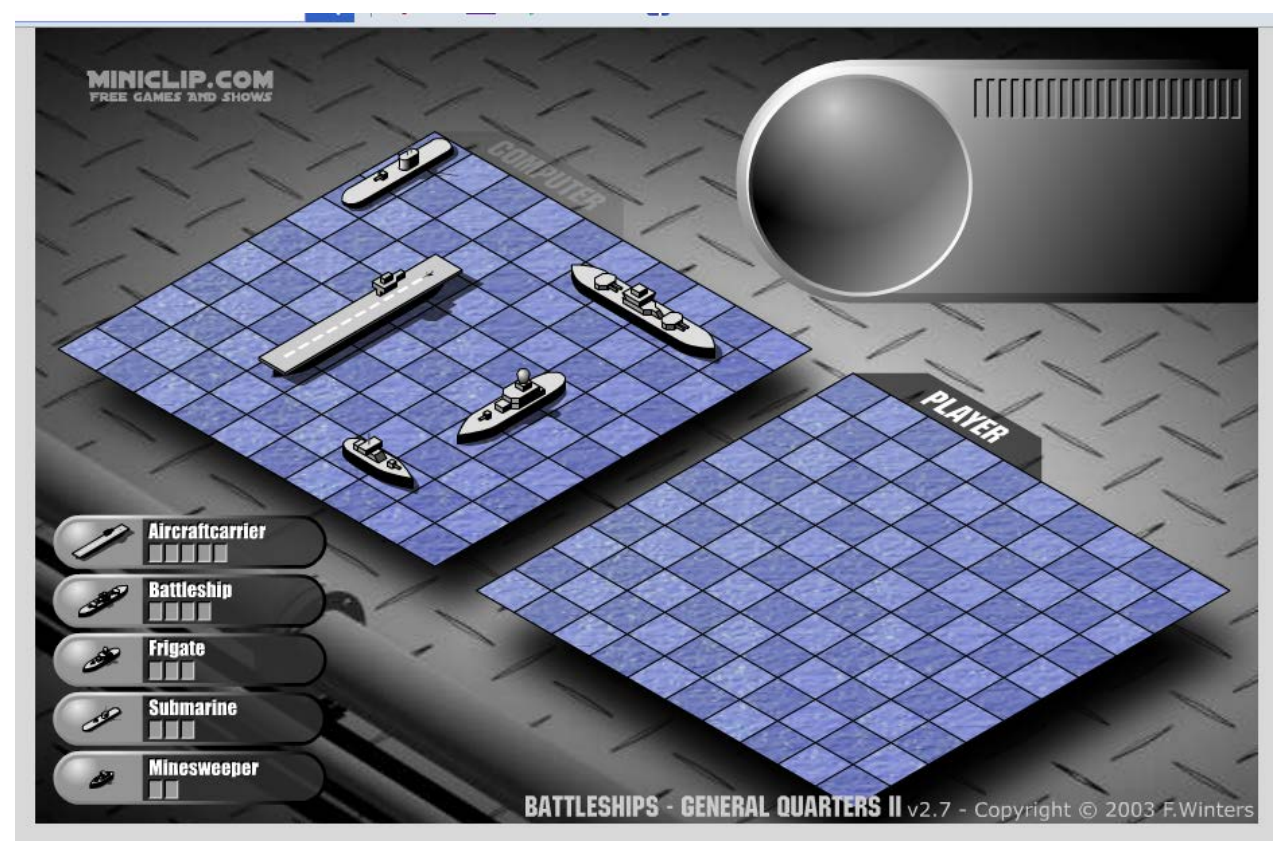

Figure 1. Battleship’s online game screen (source: http://migre.me/iM49l).

${ }^{2}$ For Tupy (2013) a geo-game is all interactive game that allows the user to further develop his knowledge of geography and the geographic space. 
An interactive game well known and which demonstrates the importance of geographical knowledge for handling it is "WAR" similar to RISK, where players compete for territories in a world map divided into regions (Europe, Asia, Africa, North America, South America and Australia). In this game, available in print and digital (online), each participant must occupy enemy territory, using their armies to attack the enemy armies. In Figure 2 we see the main screen of the game, where the knowledge of geographical strategies can decide the winner.

Following the same trend shown in WAR of strategic war games that work the potential of people and warriors, considering the geographical strategies in a fictional battlefield and enabling the user to interact online with other users worldwide through the internet, we can highlight the game called Lord of Ultima (Figure 3) where the user must manage a city that is constantly attacked by other "civilizations". Below, Figure 3 shows the initial view of this game.

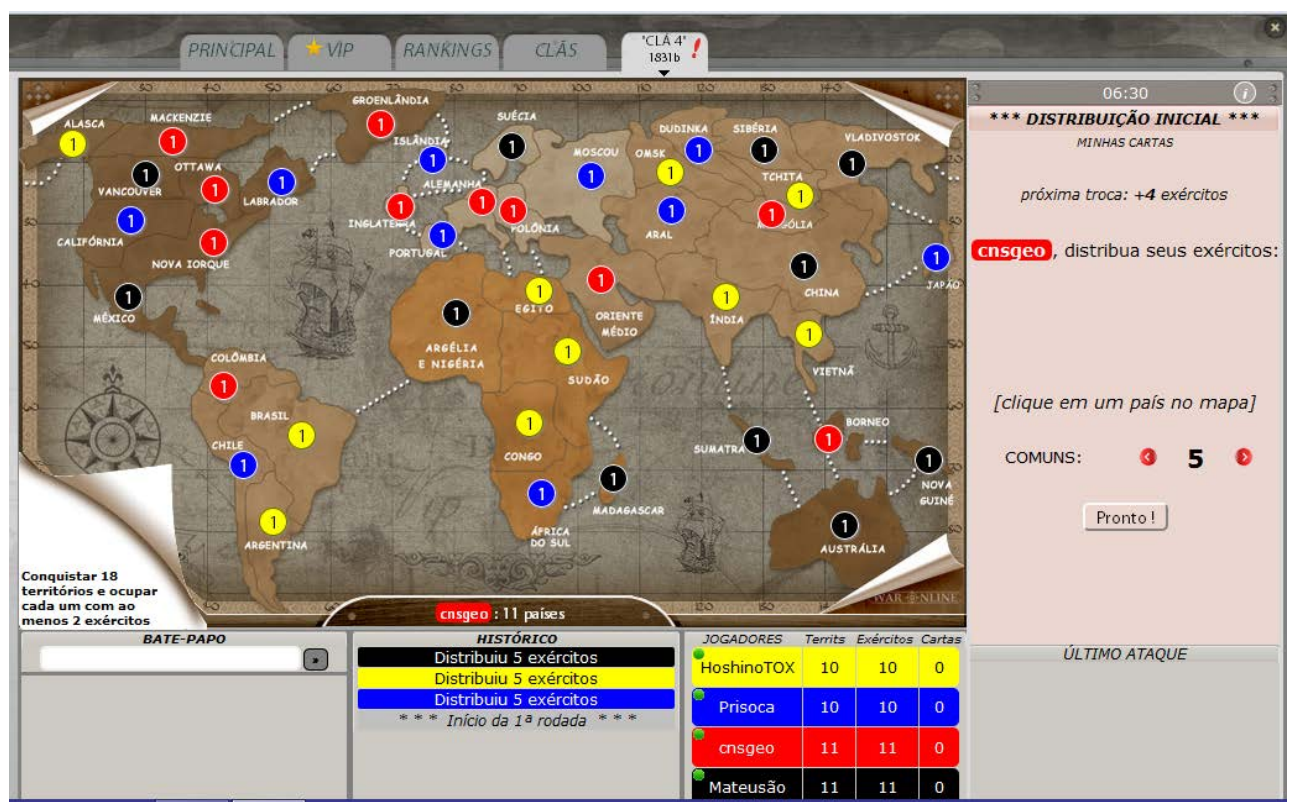

Figure 2. WAR's online game screen. (source: http://www.waronline.com.br/).

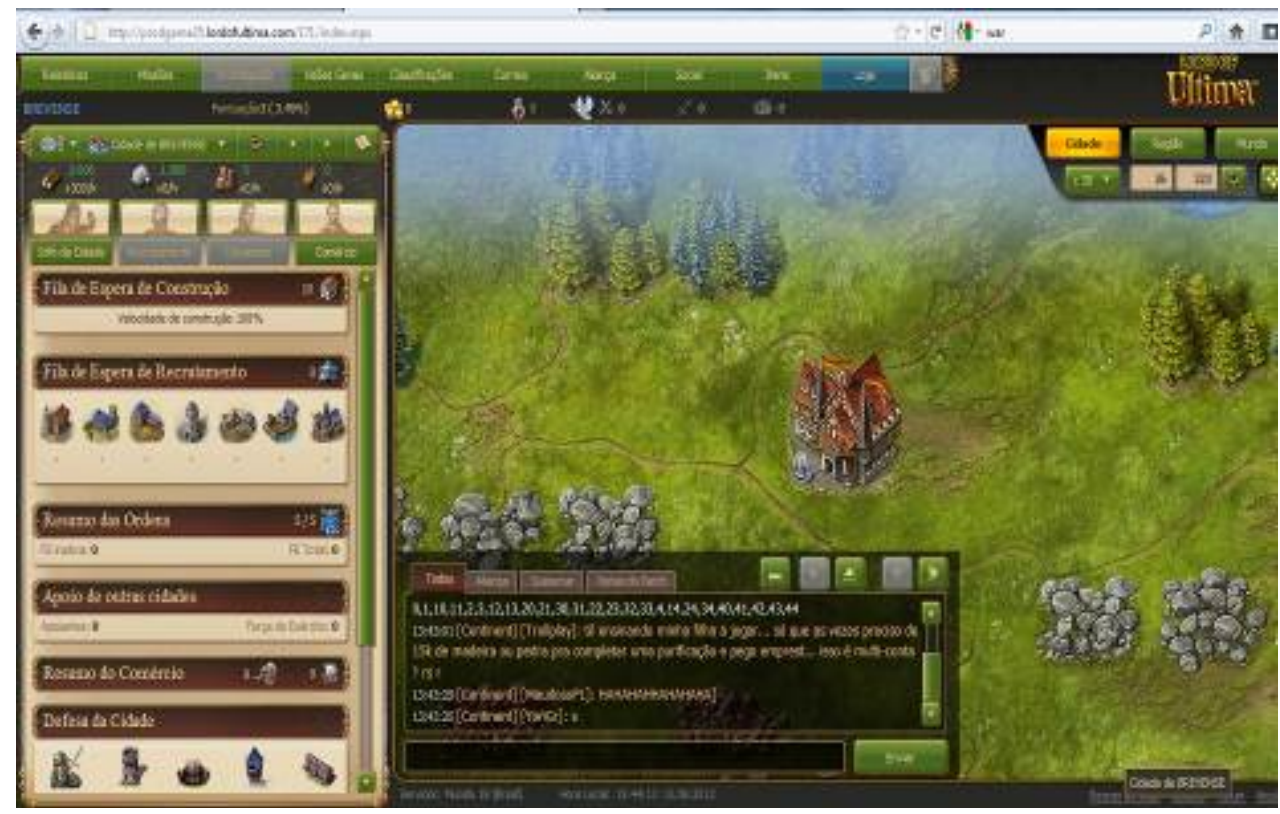

Figure 3. Lord of Ultima’s online game screen. (source: http://www.lordofultima.com). 
Games of this type, despite working with alternate realities, fictitious, inserted in the school environment enables the educator to encourage the geographical knowledge of their students so that they may see the importance of geography in understanding the geographical space to achieve a certain goal, and win. As WAR, there are other games whose geographical base is supported in the conventional world map, showing the oceans, continent and other features of earth's surface. In this case, understanding the world geographical space can be explained by the strategy that the user prints to the game, where the natural and socioeconomic characteristics of continents and countries can be worked as seen in reality.

Other digital applications, available on the internet, can host or be transformed into interactive games, such the case of Google Earth, where some authors (Andrade \& Medina, 2007; Silva \& Chaves, 2011), analyzed their potential in education of geographic space, as shown in Figure 4, which shows what is currently this WebGis ${ }^{3}$. In this case, to use Google Earth as a teaching tool, prior knowledge of its functions by the educator is necessary because this tool allows users to analyze the most diverse places on the planet, watching from high spatial resolution remote sensing images (with up to 0.5 meters), where one can distinguish the various objects on the Earth's surface, from bridges, houses, streets, even cars and other items that were previously impossible to be visualized in so-called "satellite images" with low spatial resolution, or due to distinguish the objects to be limited capacity, which differed only large objects and regions.

To use this application, the educator, student or other user has access only to the free basic version, available for download on the web. In this free version there is a possibility of manipulating and creating cartographic products based on raster files (remote sensing images) and vector files (point, line and polygon), layered, which can be activated as the user's interest with the ability to print or save the created map.

Silva \& Chaves (2011) and Andrade \& Medina (2007) reported on their experiences in using the application in classroom and observed that the use of this tool stimulates the interest of the students, facilitating the teaching of school subjects, in which:

The program allows to browse satellite images of the entire planet, rotate an image, mark and save locations, measure distances between two points and have a three-dimensional view of a particular locality. In addition to the free program, there are three more paid versions that, besides being faster, have more functions and features. (...) that make available to spatial data over the planet (Andrade \& Medina, 2007: p. 03).

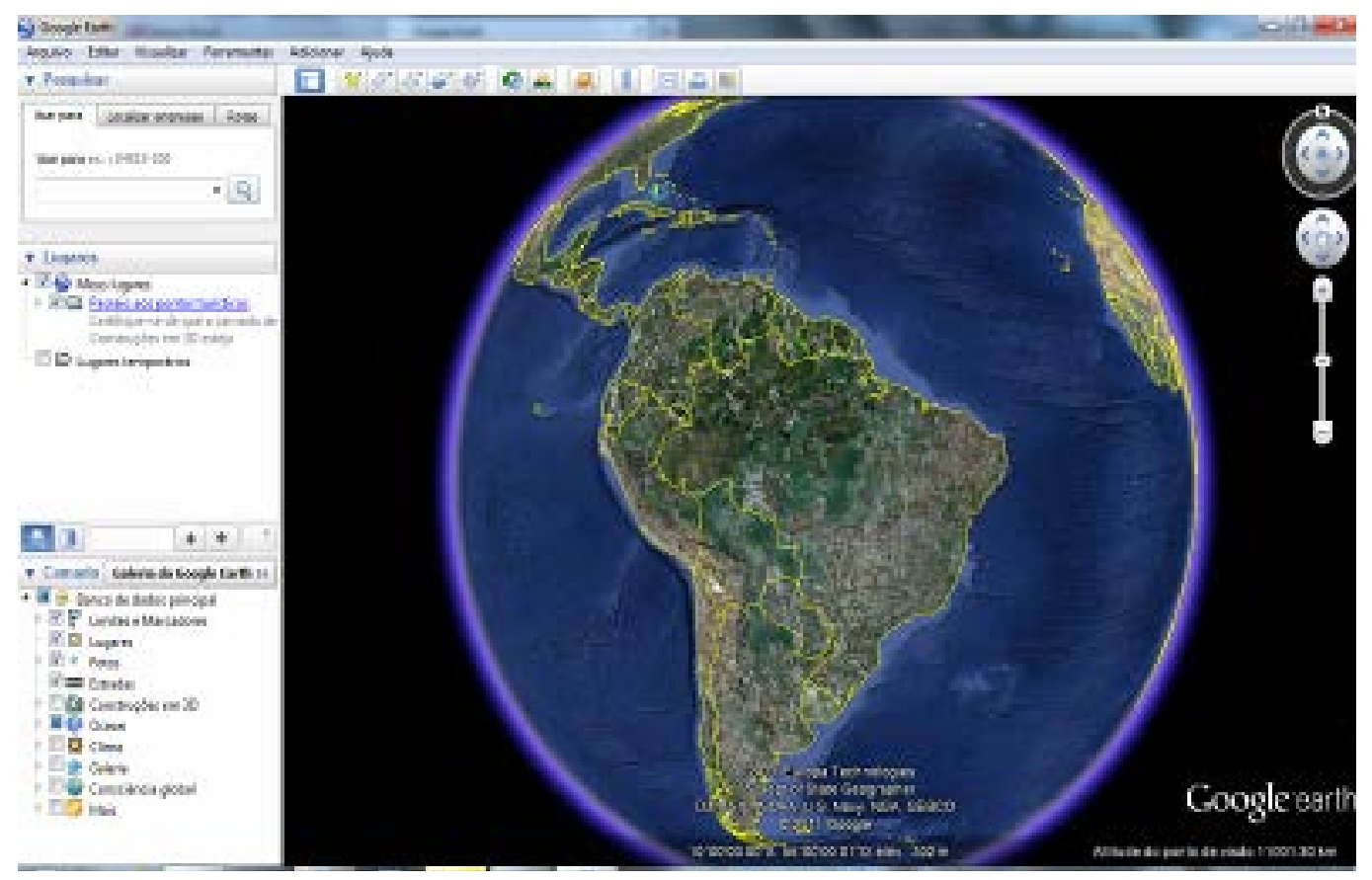

Figure 4. Google Earth’s screen. (source: http://www.google.com/intl/pt-PT/earth/index.html).

${ }^{3}$ In this case, are called Webgis those sites specializing in storage, production, handling and dissemination of cartographic product, as so-called "intelligent maps," in which the user prepares their custom map without difficulties (Schimiguel, 2004). 
For use of this tool as an interactive game it is important to know that the updates of spatial information are sporadic, independent of users and are not performed uniformly, i.e. when there is an image available in a city in 2011, does not mean all the mosaic of images from other cities in the world is also from this year but from previous years, according to contractual requirements of Google company with the owners of the sensors. However, this application allows creating vector files in .kml format, which can be converted to other formats (.shp, for example) and worked on other software that use these extensions, which gives the teacher the ability to create their own cartographic database to streamline the tool even more.

As for the scope, geographic scale, to create such applications in games is important to adapt to the subject matter in room (global, regional or local), and to use the student's reality, showing their city, street and even their home. Thus, the use of these tools in the teaching-learning process is only to increase the teaching, optimizing those classes that seemed static or dull, in which the students did not visualize the actual need to learn the subject taught. With interactive games that were presented in this paper, and there are still many to be seen, this dynamic will change, and classes will be more attractive for learning, allowing both continuous educator training, as the discovery of new places, cultures and technologies by students.

However, it is not the aim here to transform the interactive games into the main object of study in the classroom, but that these games serve as a tool in the construction of geographical knowledge, with many issues that may be in the textbooks, in order to make more dynamic and attractive to geography lesson. So, like any playful game that requires the use of the human imagination, the details that are not real should be explained as such; and the main features of the earth's surface, as they are presented in reality, should also be highlighted and discussed critically, showing students how reality can be understood through a game with apparently no link to topics discussed in class. From this, students can learn that a game in digital format, aims to "represent” a real or fictional reality where the geographical strategy is the differential.

\section{Conclusions}

This article aimed to demonstrate to the reader to use the potential tools for the teaching of geography, specifically, digital interactive games that can be used in teaching activity. For the writing of this essay, we start from the experience we have with using these tools, important information on mapping classes in basic and higher education environments.

It is necessary to emphasize that there are several other tools and activities directed to optimization of teaching practices, not only geography, but of other school subjects, which are increasingly attracting students to learn practicing in computing environment, leaving the "static" environment offered by textbooks. However, the problem is not the lack of availability of methodologies and/or specific software, but the proper selection of these tools for use in the classroom, for the simple use of cartographic representation without the necessary conceptual approach could make teaching geography and cartography mechanistic (Passini, 1994), i.e., decorative/figurative and without reflection and criticism from the students.

Thus, the constant updating and the search for new learning tools, as are the digital interactive games, have been demonstrated effectively, with new possibilities for interaction between users, with daily prepared and made available new forms of socialization (like Orkut, Facebook, Twitter, Geo Connect People, etc.), in which the geo-technologies and other digital tools should be included as another option to boost classes, not only geography, but also from all disciplines in geographic space that has its main object of study, where, maps, globes, charts, music, graphics, etc., can be inserted to make more pleasant teaching-learning process (Brito, 2011).

From the use of these tools, students can learn a digital interactive game, with maps, texts and other audio and visual resources, aiming to "represent" an effective reality or fiction, where the geographical strategy is differential. Thus, today, it is important to consider the emergence of these "connected world" tools that blend the concept of internet. Also on the Internet, there are several other samples of methodologies and activities that use digital mapping and that can be replicated elsewhere, by other professionals, which can be adapted to the teacher and student reality and, depending on the subject, may bring new questions to critical debate in the classroom about the geographical space.

Thus, it is necessary to emphasize that there are several other tools and activities directed to optimization of teaching practices, not only geography, but of other school subjects, which are increasingly attracting students to learn practicing in computing environment, leaving the environment "static" offered by textbooks (Silva, 2013a). We should also emphasize that the development or application of tools such as digital games as well as the use 
of all other types of teaching methods, conform to the type of user that will be made available; because the application must be thought according to a users hierarchy (beginner, intermediate and advanced), which should have different restrictions and permissions, in case of changes, upload and download (Silva, 2013b). However, it is important to recognize that digital interactive games, nowadays, are important tools for the dissemination of spatial information and have great potential in the construction of geographical knowledge.

\section{Funding}

This research was funded by the Qualified Publication Support Program (PAPQ), offered by the Dean of Research and Graduate Studies (PROPESP) and the Foundation for the Support and Development of Research (FADESP), of the Federal University of Pará.

\section{References}

Andrade A. F., \& Medina, S. S. S. (2007). The Use of Satellite Images from Google Earth as a Teaching Resource for Teaching Covers Projections. Curitiba: Graphica.

Brito, M. S. (2011). The Use of Geographical Atlas and Encyclopedias on CD-ROM in the Teaching of Geography (O uso de atlas e enciclopédias geográficas em CD-ROM no ensino-aprendizagem da geografia).

http://www.cartografia.ime.eb.br/artigos/epq1.pdf

Cavalcanti, L. S. (2002). Geography and Teaching Practices (Geografia e práticas de ensino). Goiânia: Alternative.

Francischett, M. N. (2011). The Map in the Teaching and Learning of Geography (A cartografia no ensino-aprendizagem da geografia). http://www.bocc.ubi.pt/pag/francischett-mafalda-representacoes-cartograficas.pdf

Lacoste, Y. (1989). The Geography-That Serve, First to Make War (A Geografia-Isso Serve, em Primeiro Lugar, para Fazer a Guerra). Sao Paulo: Papirus Publisher.

Moreira, R. (2006). Where Does the Geographic Thought? For a Critical Epistemology (Para onde vai o pensamento Geográfico? Por uma epistemologia crítica). São Paulo: Contexto. Neves, S. C., Nascimento, D. C. S., \& Carvalho, J. S. (2013). The Mapping Associated with the Board Game as an Important Resource for the Teaching of Geography (A cartografia associada ao jogo de tabuleiro como

um importante recurso didático para o ensino de geografia). In C. N., Silva, V. N. S., Caetano, \& A. Oliveira Neto (Eds.), Geography Education and Representation of Geographical Space (pp. 307-330). Belém: GAPTA/UFPA.

Passini, E. Y. (1994). Literacy Cartographic and the Textbook: A Critical Analysis (Alfabetização cartográfica e o livro didático: Uma análise crítica). Belo Horizonte: Ed. Lê.

Schimiguel, J. (2004). Investigating Interaction Aspects in GIS Web Applications Focused on the Agricultural Domain (Investigando Aspectos de Interação em Aplicações SIG na Web voltadas ao Domínio Agrícola). Sixth Symposium on Human Factors in Computing Systems_Facilitating and Transforming Everyday, Bourbon Hotel, Curitiba, 2004, 113-121.

Selbach, S. (2010) Geography and Didactic (Geografia e didática). Petropolis: Vozes.

Silva, A. P. A., \& Chaves, J. M. (2011). Use of Google Maps and Google Earth in High School: A Case Study in Police State College Military-Diva Portela in Feira de Santana, Bahia (Utilização do Google Maps e Google Earth no ensino médio: Estudo de caso no Colégio Estadual da Polícia Militar-Diva Portela em Feira de Santana-BA). XV Brazilian Symposium on Remote Sensing—SBSR, Curitiba, 2011, 3220-3226.

Silva, C. N. (2013a). The Spatial Representation and the Cartographic Language (A representação espacial e a linguagem cartográfica). Belém: GAPTA/UFPA.

Silva, C. N. (2013b). Tools Applied in the Mapping of Teaching: The Digital Geographic Atlas, the Webgis and Interactive Digital Games (Ferramentas aplicadas no ensino de cartografia: O atlas geográfico digital, o webgis e os jogos digitais interativos). Geosaberes: Journal of Geoeducacionais Studies, 4, 50-60. http://migre.me/ozXpR

Silva, C. N. (2003). Public Education, Teaching of Geography and the Academic Context (O ensino público, ensino de Geografia e o contexto academic). Geographic Magazine Science, 9, 281-284.

Sposito, E. S. (2006). Textbooks of History and Geography: Evaluation and Research (Livros didáticos de História e Geografia: Avaliação e pesquisa). Sao Paulo: Academic Culture.

Straforini, R. (2004). Teaching Geography: The Challenge of All-World in the Early Grades (Ensinar geografia: O desafio da totalidade-mundo nas séries iniciais). Sao Paulo: Annablume.

Taylor, D. R. F. (2010). A Conceptual Basis for Cartography: New Directions for the Information Age (Uma base conceitual para a cartografia: Novas direções para a era da informação). Revista Portal de Cartografia das Geociências, 3.

http://www.uel.br/revistas/uel/index.php/portalcartografia 
Tupy, F. (2013). Video and Geography: A Landmark Intersection in Real Landscapes, Virtual, Play and Learning (Videogames e geografia: Um marco de intersecção nas paisagens reais, virtuais, lúdicas e de aprendizagem). In C. N. Silva, V. N. S. Caetano, \& A. Oliveira Neto (Eds.), Geography Education and Representation of Geographical Space (pp. 33-46). Belém: GAPTA/UFPA. 